\title{
ANALISIS KELAYAKAN USAHA ARMADA PUKAT CINCIN TERI DENGAN PERBANDINGAN UKURAN KAPAL 5GT, 10GT, DAN 15GT
}

\author{
Business Feasibility Analysis on Purse Seine Teri Fleet with Ship Size Comparative 5 GT, 10 GT, and \\ $15 G T$ \\ Oleh: \\ Koko Hardito ${ }^{1}$, Chandra Nainggolan², Priyanto Rahardjo ${ }^{2}$ \\ ${ }^{1}$ Program Pasca Sarjana, Politeknik Ahli Usaha Perikanan- \\ Pasar Minggu, Jakarta \\ 2 Politeknik Ahli Usaha Perikanan-Pasar Minggu, Jakarta \\ *Korespondensi penulis: khardito66@gmail.com
}

\begin{abstract}
ABSTRAK
Penelitian ini bertujuan menganalisis usaha perikanan dari kelayakannya pada armada pukat cincin teri dengan perbandingan ukuran yang dinilai memiliki perbedaan yang signifikan, yaitu 5 GT, 10 GT dan 15 GT. Penelitian dilakukan mulai tanggal 1 Oktober 2020 sampai 31 Desember 2020 pada armada pukat cincin teri yang berpangkalan di PPP. Larangan, Kabupaten Tegal. Metode survei yang digunakan dalam penelitian ini adalah metode pengumpulan data yang dilakukan dengan cara meninjau, mengamati, dan mengambil data dan informasi di lapangan secara langsung dengan menggunakan alat pengumpulan data yang utama berupa kuesioner. Hasil penelitian ini menunjukkan bahwa investasi pukat cincin teri ukuran kapal 5 GT membutuhkan modal usaha sebesar Rp363.134.000, investasi pukat cincin teri ukuran kapal $10 \mathrm{GT}$ membutuhkan modal usaha sebesar Rp535.200.000, sedangkan investasi pukat cincin teri ukuran kapal 15 GT membutuhkan modal usaha sebesar Rp646.220.000. Kriteria investasi pukat cincin teri ukuran kapal 5 GT menghasilkan NPV= Rp290.569.703, IRR $=14 \%, R / C$ ratio $=1,38, \mathrm{BEP}=\mathrm{Rp} 109.682 .332, \mathrm{PP}=4,42$, dan $\mathrm{ROI}=22,68 \%$. Kriteria investasi pukat cincin teri ukuran kapal $10 \mathrm{GT}$ menghasilkan NPV= $\mathrm{Rp} 470.448 .109, \mathrm{IRR}=15 \%, R / C$ ratio $=1,41, \mathrm{BEP}=\mathrm{Rp} 150.856 .418, \mathrm{PP}=4,04$, dan $\mathrm{ROI}=24,85 \%$. Sedangkan kriteria investasi pukat cincin teri ukuran kapal 15 GT menghasilkan NPV= $\mathrm{Rp} 141.442 .890, \mathrm{IRR}=4 \%, R / C$ ratio $=1,24, \mathrm{BEP}=\mathrm{Rp} 192.493 .553, \mathrm{PP}=8,93$, dan $\mathrm{ROI}=11,20 \%$. Hal ini menunjukkan bahwa usaha pukat cincin teri ukuran kapal 10 GT dan 5 GT lebih layak dilanjutkan dan dijalankan dibandingkan pukat cincin teri ukuran kapal 15 GT.
\end{abstract}

Kata kunci: investasi, kelayakan usaha, PPP Larangan, pukat cincin teri

\section{ABSTRACT}

This study aims to analyze the fishery business from its feasibility in an anchovy purse seiner with a size comparison that is considered to have significant differences, namely 5 GT, 10 GT and 15 GT. The research was conducted from October 1, 2020 to December 31, 2020 on an anchovy purse seiner based at PPP. Larangan, Tegal Regency. The survey method used in this research is the method of collecting data by reviewing, observing, and taking data and information in the field directly using the main data collection tool in the form of a questionnaire. The study's results are an investment in anchovy purse seiner with a size of 5 GT requires a business capital of Rp363.134,000, an investment in an anchovy purse seiner with a size of 10 GT requires a working capital of Rp535,200,000, while the investment in an anchovy purse seiner is the size of the 15 GT ship requires a business capital of $R p 646,220,000$. Investment criteria for an anchovy purse seiner with ship size 5 GT resulted in NPV= $R p 290.569 .703, I R R=14 \%, R / C$ ratio $=1.38, B E P=R p 109.682 .332, P P=4.42$, and $R O I=22.68 \%$. Investment criteria for an anchovy purse seiner with a ship size of 10 GT produces NPV= 
Rp470.448.109, $I R R=15 \%, R / C$ ratio $=1.41, B E P=R p 150,856,418, P P=4.04$, and $R O I=24.85 \%$. While the investment criteria for an anchovy purse seiner with ship size 15 GT resulted in NPV= $R p 141.442 .890, I R R=4 \%, R / C$ ratio $=1.24, B E P=R p 192,493,553, P P=8.93$, and $R O I=11.20 \%$. This shows that anchovy purse seiner with a size of 10 GT and 5 GT are more feasible to continue and run than anchovy purse seiner with a size of 15 GT.

Key words: anchovy purse seiner, business feasibility, investment, PPP Larangan

\section{PENDAHULUAN}

Usaha perikanan yang berbasis pada kegiatan penangkapan ikan dan/atau kegiatan pengangkutan ikan merupakan pengertian dari usaha perikanan tangkap, hal ini dinyatakan dalam Peraturan Menteri Kelautan dan Perikanan nomor 58/PERMEN-KP/2020 tentang perikanan tangkap. Usaha perikanan tangkap yang ada di wilayah laut Kabupaten Tegal didominasi oleh armada pukat cincin teri. Menurut data yang dimiliki oleh Kantor Pelabuhan Perikanan Pantai Larangan (PPP Larangan) tercatat ada 132 kapal penangkap dengan 3 jenis alat penangkap ikan, antara lain 70 armada pukat cincin teri, 44 armada payang gemplo, dan 18 armada arad (PPP Larangan, 2020).

Penentuan satuan volume kapal biasa disebut dengan GT (gross tonnage)/tonase kotor kapal, hal ini dinyatakan dalam Pasal 1 butir 6, Peraturan Pemerintah (PP) Republik Indonesia Nomor 7 Tahun 2000 tentang Kepelautan, disebut dengan GT/tonase kotor kapal. Kapal-kapal pukat cincin teri (armada penangkapan ikan dominan) yang ada di Kabupaten Tegal memiliki beragam ukuran, yang tiap ukuran kapalnya mempengaruhi besaran/ukuran mesin dan alat tangkap serta biaya operasional yang digunakannya secara berbeda-beda. Berdasarkan perbedaan-perbedaan tersebut, maka seluruh armada penangkapan yang ada dapat digolongkan ke dalam 3 (tiga) golongan ukuran kapal yang memiliki perbedaan signifikan, yaitu kapal 5 GT, 10 GT dan 15 GT.

Nelayan yang memiliki/mengoperasikan kapal dengan ukuran paling besar 5 GT termasuk ke dalam golongan nelayan kecil menurut (UU No. 45, 2009), sedangkan pada (UU No. 7, 2016) terdapat perbedaan dimana spesifikasi penggolongan nelayan kecil adalah nelayan yang mengoperasikan kapal paling besar 10 GT. Penentuan rentang sebesar 5 GT inilah yang mendasari pengambilan sampel yang dijadikan objek penelitian.

Bersumber dari data ketiga kapal tersebut akan diteliti dan dianalisa tentang kelayakan finansial usahanya, dengan tujuan untuk mengetahui usaha layak dijalankan atau tidak (Kusuma \& Mayasti, 2014), sehingga dapat dilihat dan ditentukan kapal yang memiliki kelayakan usaha terbaik dari ketiganya guna merekomendasikan kepada pemilik modal/pengusaha yang sudah maupun baru ingin terjun kebidang usaha perikanan tangkap dengan komoditas teri, khususnya di wilayah Kabupaten Tegal dan WPP-NRI (Wilayah Pengelolaan Perikanan Negara Republik Indonesia) pada umumnya.

\section{METODE PENELITIAN}

Metode survei yang digunakan dalam penelitian ini adalah metode pengumpulan data yang dilakukan dengan cara meninjau, mengamati, dan mengambil data dan informasi di lapangan secara langsung dengan menggunakan alat pengumpulan data yang utama berupa kuesioner (Jakfar 2009).

Metode Pengumpulan Data

Tanggal 1 Oktober 2020 sampai dengan 31 Desember 2020 Penelitian ini dilaksanakan. Yang menjadi lokasi penelitian adalah Pelabuhan Perikanan Pantai (PPP) Larangan yang merupakan sentra pendaratan ikan bagi nelayan Kabupaten Tegal, Provinsi Jawa Tengah. Data primer dan data sekunder merupakan data yang digunakan dalam penelitian ini. Data-data yang diperoleh dari hasil observasi 
dan wawancara dengan kuesioner meliputi data teknis kapal dan alat tangkap pukat cincin teri serta data ekonomi usaha (biaya operasional, jenis dan jumlah hasil tangkapan yang diperoleh per trip) merupakan data primer. Sedangkan data sekunder diperoleh dari studi pustaka meliputi data time series produksi dari alat tangkap pukat cincin teri, jumlah hasil tangkapan per hari tiap kapal (buku bakul), harga ikan per jenis per kilogram, jumlah trip per bulan dalam 1 tahun.

Penentuan Responden

Jumlah pukat cincin teri ukuran 5 GT, 10 GT, dan 15 GT yang berpangkalan di Pelabuhan Perikanan Pantai Larangan terlihat pada Tabel 1.

Tabel 1 Jumlah kapal pukat cincin teri berukuran 5 GT, 10 GT, dan 15 GT yang berpangkalan di Pelabuhan Perikanan Pantai Larangan

\begin{tabular}{clll}
\hline No & \multicolumn{1}{c}{ 5 GT } & \multicolumn{1}{c}{10 GT } & \multicolumn{1}{c}{15 GT } \\
\hline 1 & KM. Bima Karya-4 (5) & KM. Karya Baru Group-1 (10) & $\begin{array}{l}\text { KM. Sri Nanjung Jaya-2 (15) } \\
\text { KM. Karya Baru Group-2 } \\
(15)\end{array}$ \\
3 & KM. Karya Mitra (5) & KM. Mustika Sari HFD (10) & \\
4 & KM. Subur Baru (5) & KM. Mutiara Jaya SN (10) & \\
5 & KM. maju makmur NK (5) & KM. Mekar Maju-01 (10) & \\
6 & & KM. Reza Jaya SW (10) & \\
7 & & KM. Kota Santi (10) & 2 \\
\hline Jumlah & 5 & 7 & \\
\hline
\end{tabular}

Berdasarkan Tabel 1, terdapat 5 unit kapal pukat cincin teri berukuran 5 GT, 7 unit kapal pukat cincin teri berukuran $10 \mathrm{GT}$, dan 2 unit kapal pukat cincin teri berukuran 15 GT yang berpangkalan di PPP. Larangan, sehingga penentuan responden yang diambil berjumlah 14 orang nakhoda dari 14 unit kapal tersebut.

Metode Analisis Data

Analisis Teknis

Menurut (Sobari \& Isnaini, 2009), analisis teknis dilakukan dengan metode deskriptif dengan memberikan gambaran kegiatan usaha perikanan tangkap pukat cincin teri di PPP. Larangan. Unit penangkapannya meliputi konstruksi alat tangkap pukat cincin, operasi penangkapan pukat cincin dan hasil tangkapan pukat cincin.

Aspek Biaya

Usaha perikanan tangkap memiliki dua aspek biaya yaitu biaya tetap (fixed cost) dan biaya tidak tetap (variable cost). Biaya total dapat dirumuskan dengan persamaan (Putri \& Dewi 2019).

$$
B=B T+B V
$$

Keterangan:

B : Biaya total $(\mathrm{Rp})$

$\mathrm{BV}$ : Biaya variabel $(\mathrm{Rp})$

$\mathrm{BT}$ : Biaya tetap $(\mathrm{Rp})$

Nilai Penyusutan 
Nilai penyusutan dihitung sebagai nilai untuk menggantikan alat produksi yang sudah tidak ekonomis lagi (Sayuti 2008). Rumus nilai penyusutan alat produksi dapat dituliskan dengan persamaan (Putri \& Dewi 2019).

$$
\mathrm{NP}=\frac{\mathrm{HB}-\mathrm{HS}}{\mathrm{T}}
$$

Keterangan:

$\mathrm{NP}$ : Nilai penyusutan $(\mathrm{Rp})$

$\mathrm{HB}$ : Harga beli $(\mathrm{Rp})$

HS : Harga sisa $(\mathrm{Rp})$

$\mathrm{T}$ : waktu pakai (tahun)

Analisis Penerimaan dan Pendapatan

Nilai penjualan dari hasil penangkapan merupakan pengertian dari analisis penerimaan dalam usaha penangkapan ikan dengan alat tangkap pukat cincin teri (Pujianto \& Wijayanto 2013). Secara sistematis, penerimaan dapat dihitung dengan persamaan.

$$
\operatorname{Pr}=\sum B x H
$$

Keterangan:

$\operatorname{Pr} \quad$ : Penerimaan $(\mathrm{Rp})$

$\sum$ B : Jumlah produksi $(\mathrm{Rp})$

$\mathrm{H} \quad$ : Harga jual ikan $(\mathrm{Rp})$

Secara matematis pendapatan adalah selisih antara jumlah penerimaan dengan biaya total. Perhitungan pendapatan untuk mengetahui rugi/ laba menggunakan rumus Coelli et al. (1998) dalam (Suharyanto et al. 2020), sesuai persamaan.

$$
\pi=T R-T C
$$

Keterangan:

$$
\begin{array}{ll}
\pi & : \text { Pendapatan (rugi/laba) per trip } \\
\text { TR } & : \text { Total Revenue (total penerimaan) } \\
\text { TC } & : \text { Total Cost (Total biaya operasional) }
\end{array}
$$

Analisis Finansial Kelayakan Usaha Pukat Cincin Teri

a. NPV (Net Present Value)

Tingkat bunga yang relevan digunakan untuk menghitung nilai sekarang (Sayuti 2008). Rumus yang digunakan dapat dilihat pada persamaan.

$$
N P V=\sum_{a=1}^{n} N B(1+i)^{-n}
$$

Keterangan:

$$
\begin{array}{ll}
\mathrm{NB} & : \text { Net Revenue } \\
\mathrm{n} & : \text { Tahun } \\
\mathrm{i} & : \text { Discount Factor }
\end{array}
$$

Kriteria hasil perhitungan NPV adalah:

- $\quad \mathrm{NPV}>0$, usulan usaha diterima

- $\quad \mathrm{NPV}<0$, usulan usaha tidak diterima

- $\mathrm{NPV}=0$ nilai perusahaan tetap walau usulan usaha diterima ataupun tidak diterima

b. IRR (Internal Rate of Return)

Digunakan untuk mencari tingkat bunga yang menyamakan nilai sekarang dari arus kas yang diharapkan dimasa datang, atau penerimaan kas, dengan mengeluarkan investasi awal digunakanlah Metode ini (Husein 2015). Menurut (Setyawan et al. 2013), IRR sebagai nilai 
indikator yang akan menyamakan present value cash inflow dengan jumlah modal dari nilai proyek yang sedang dinilai. Untuk metode ini dapat dilihat dengan rumus persamaan berikut.

$$
I R R=i_{1}\left(\frac{N P V_{1}}{N P V_{1}-N P V_{2}}\right)\left(i_{2}-i_{1}\right)
$$

Keterangan:

$\mathrm{i}_{1} \quad$ : tingkat DF yang menghasilkan NPV1

i2 $_{2}$ : tingkat DF yang menghasilkan NPV2

Kriteria investasi dari IRR adalah jika IRR yang didapat lebih besar dari nilai rate of return maka usulan investasi dapat diterima.

c. R/C Ratio

R/C Ratio dapat dihitung dengan persamaan (Sofyani 2012).

$$
\frac{\mathrm{R}}{\mathrm{C}} \text { Ratio }=\frac{\text { Total Pendapatan }}{\text { Total Biaya }}
$$

Kriteria hasil perhitungan $R / C$ Ratio adalah:

$R / C$ Ratio $>1$, berarti usaha memperoleh keuntungan sehingga usaha layak dijalankan.

$R / C$ Ratio $=1$, usaha tidak memperoleh keuntungan dan tidak mengalami kerugian (impas)

$R / C$ Ratio $<1$, usaha mengalami kerugian sehingga tidak layak dijalankan

d. BEP (Break Event Point)

Suatu keadaan dimana dalam kegiatan usaha, perusahaan tidak memperoleh keuntungan dan tidak mengalami kerugian disebut BEP (Jakfar 2009). BEP dapat dihitung menggunakan persamaan sebagai berikut.

$$
\mathrm{BEP}(\mathrm{Rp})=\frac{\text { Biaya tetap }}{1-\frac{\text { Biaya variabel }}{\text { Hasil Penjualan }}}
$$

e. PP (Payback Period)

Perbandingan initial cash investment dengan cash inflow nya menghasilkan satuan waktu disebut payback period. Kemudian nilai pebandingan ini dibagi dengan payback period maksimum yang dapat diterima (Sayuti 2008). Payback period dapat dihitung menggunakan persamaan sebagai berikut.

$$
\text { Payback Period }=\frac{\text { Nilai investasi }}{\text { Kas masuk bersih }} \times 1 \text { tahun }
$$

Semakin cepat nilai payback period maka semakin bagus untuk dilakukan investasi, hal ini menyatakan kriteria studi kelayakan karena semakin lancar perputaran modal.

f. ROI (Return On Investment)

ROI adalah perbandingan uang yang diperoleh atau hilang pada suatu investasi terhadap jumlah uang yang diinvestasikan. ROI dapat dihitung menggunakan rumus dengan persamaan sebagai berikut.

$$
\text { ROI }=\frac{(\text { Total penjualan-Investasi })}{\text { Investasi }} \times 100 \%
$$




\section{HASIL DAN PEMBAHASAN}

\section{Analisis Biaya Perikanan Pukat Cincin Teri}

Biaya Investasi

Total biaya yang dikeluarkan untuk memulai suatu investasi usaha perikanan tangkap di PPP. Larangan dapat dilihat pada Tabel 2.

Tabel 2 Biaya investasi usaha perikanan tangkap pukat cincin teri di PPP Larangan tahun 2020

\begin{tabular}{lccccc}
\hline & $\begin{array}{c}\text { Harga Kapal } \\
(\mathrm{Rp})\end{array}$ & $\begin{array}{c}\text { Harga Mesin } \\
(\mathrm{Rp})\end{array}$ & $\begin{array}{c}\text { Harga Alat } \\
\text { tangkap (Rp) }\end{array}$ & $\begin{array}{c}\text { Harga Alat } \\
\text { bantu (Rp) }\end{array}$ & $\begin{array}{c}\text { Jumlah } \\
(\mathrm{Rp})\end{array}$ \\
\hline Kapal Ukuran 5 GT & & & & & \\
\hline Min & 98.000 .000 & 92.000 .000 & 135.000 .000 & 22.000 .000 & 354.000 .000 \\
Max & 110.000 .000 & 97.000 .000 & 150.000 .000 & 26.000 .000 & 379.000 .000 \\
Average & 101.900 .000 & 95.034 .000 & 142.000 .000 & 24.200 .000 & 363.134 .000 \\
\hline Kapal Ukuran 10 GT & & & & & \\
\hline Min & 180.000 .000 & 149.000 .000 & 155.000 .000 & 24.000 .000 & 508.000 .000 \\
Max & 185.000 .000 & 158.000 .000 & 175.000 .000 & 26.800 .000 & 544.600 .000 \\
Average & 185.000 .000 & 154.985 .714 & 169.428 .571 & 25.785 .714 & 535.200 .000 \\
\hline Kapal Ukuran 15 GT & & & & \\
\hline Min & 205.000 .000 & 197.000 .000 & 202.000 .000 & 25.000 .000 & 640.440 .000 \\
Max & 215.000 .000 & 198.440 .000 & 215.000 .000 & 35.000 .000 & 652.000 .000 \\
Average & 210.000 .000 & 197.720 .000 & 208.500 .000 & 30.000 .000 & 646.220 .000 \\
\hline \multicolumn{7}{l}{} & & & & & \\
\hline
\end{tabular}

Berdasarkan data pada Tabel 2, terlihat bahwa kapal berukuran 5 GT, 10 GT dan 15 GT memerlukan biaya investasi yang linier yaitu semakin besar ukuran kapal maka semakin besar pula biaya investasinya.

Menurut Sutrisno (2007) dalam Fachrussyah \& Yantu (2018), biaya tetap (fixed cost) merupakan biaya yang nilainya tidak mengalami perubahan, berapapun jumlah barang/produk yang dihasilkan. Biaya tetap usaha penangkapan menggunakan alat tangkap pukat cincin teri, yaitu biaya penyusutan dan biaya perawatan. Berdasarkan Tabel 2 dapat dihitung nilai penyusutannya pada Tabel 3.

Tabel 3 Rata-rata biaya penyusutan aset armada pukat cincin teri per tahun

\begin{tabular}{|c|c|c|c|c|c|}
\hline & \multicolumn{5}{|c|}{ Jenis Penyusutan } \\
\hline & Kapal & Mesin & Alat tangkap & Alat bantu & Jumlah \\
\hline \multicolumn{6}{|c|}{ Kapal Ukuran 5 GT } \\
\hline Min & 8.820 .000 & 7.500 .000 & 13.500 .000 & 2.000 .000 & 33.138 .333 \\
\hline Max & 9.900 .000 & 9.812 .500 & 16.250 .000 & 2.666 .667 & 37.962 .500 \\
\hline Average & 9.171 .000 & 8.604 .250 & 14.950 .000 & 2.366 .667 & 35.091 .917 \\
\hline \multicolumn{6}{|c|}{ Kapal Ukuran 10 GT } \\
\hline Min & 16.200 .000 & 13.125 .000 & 11.250 .000 & 2.200 .000 & 44.125 .000 \\
\hline Max & 17.550 .000 & 16.175 .000 & 18.125 .000 & 2.800 .000 & 54.350 .000 \\
\hline Average & 16.650 .000 & 15.105 .357 & 14.142 .857 & 2.428 .571 & 48.326 .786 \\
\hline \multicolumn{6}{|c|}{ Kapal Ukuran 15 GT } \\
\hline Min & 17.550 .000 & 14.925 .000 & 18.125 .000 & 2.500 .000 & 53.100 .000 \\
\hline Max & 18.450 .000 & 19.000 .000 & 22.500 .000 & 3.333 .333 & 63.283 .333 \\
\hline Average & 18.000 .000 & 16.962 .500 & 20.312 .500 & 2.916 .667 & 58.191 .667 \\
\hline
\end{tabular}


Tabel 4 Rata-rata biaya perawatan armada penangkapan nelayan pukat cincin teri di PPP. Larangan tahun 2020

\begin{tabular}{|c|c|c|c|c|c|}
\hline & \multicolumn{5}{|c|}{ Jenis Perawatan } \\
\hline & Doking & Mesin & Alat tangkap & Alat bantu & Jumlah \\
\hline \multicolumn{6}{|c|}{ Kapal Ukuran 5 GT } \\
\hline Min & 4.250 .000 & 2.500 .000 & 4.500 .000 & 500.000 & 12.150 .000 \\
\hline Max & 4.550 .000 & 3.000 .000 & 5.000 .000 & 500.000 & 13.000 .000 \\
\hline Average & 4.410 .000 & 2.760 .000 & 4.850 .000 & 500.000 & 12.520 .000 \\
\hline \multicolumn{6}{|c|}{ Kapal Ukuran 10 GT } \\
\hline Min & 4.900 .000 & 3.800 .000 & 6.800 .000 & 500.000 & 16.250 .000 \\
\hline Max & 5.800 .000 & 4.200 .000 & 7.300 .000 & 500.000 & 17.300 .000 \\
\hline Average & 5.335 .714 & 3.971 .429 & 7.085 .714 & 500.000 & 16.892 .857 \\
\hline \multicolumn{6}{|c|}{ Kapal Ukuran 15 GT } \\
\hline Min & 6.000 .000 & 5.000 .000 & 7.500 .000 & 500.000 & 19.000 .000 \\
\hline Max & 6.500 .000 & 5.500 .000 & 8.000 .000 & 500.000 & 20.500 .000 \\
\hline Average & 6.250 .000 & 5.250 .000 & 7.750 .000 & 500.000 & 19.750 .000 \\
\hline
\end{tabular}

Dengan demikian, dalam pengoperasian kapal pukat cincin teri 5 GT, 10 GT, dan 15 GT memerlukan total biaya tetap setiap tahunnya dengan perincian pada Tabel 5.

Tabel 5 Total biaya tetap per tahun

\begin{tabular}{llrrr}
\hline \multirow{2}{*}{ No. } & \multirow{2}{*}{ Jenis Biaya Tetap } & \multicolumn{3}{c}{ Biaya Tetap (Rp) } \\
\cline { 3 - 5 } & Penyusutan & 35.091 .917 & $10 \mathrm{GT}$ & \multicolumn{1}{c}{$15 \mathrm{GT}$} \\
\hline 1 & Perawatan & 12.520 .000 & 48.326 .786 & 58.191 .667 \\
2 & Jumlah & 47.611 .917 & 16.892 .857 & 19.750 .000 \\
\hline
\end{tabular}

Berdasarkan data pada Tabel 2-4, terlihat bahwa pada kapal berukuran 5 GT, 10 GT dan 15 GT memiliki beban biaya penyusutan dan rata-rata biaya perawatan yang linier, sehingga total biaya tetap per tahunnya juga linier, semakin besar ukuran kapal maka semakin besar pula total biaya tetap per tahunnya.

Biaya Tidak Tetap/Variabel

Menurut Sutrisno (2007) dalam Fachrussyah \& Yantu (2018), biaya tidak tetap (variable cost) merupakan biaya bervariasi yang besarannya tergantung jumlah barang/ produk yang dihasilkan. Biaya variabel pada penelitian ini meliputi biaya operasional, pungutan lelang, dan bagi hasil nelayan. Rincian rata-rata biaya operasional nelayan pukat cincin teri dapat dilihat pada Tabel 6 .

Jumlah pungutan lelang adalah sebesar 5\% dari hasil produksi kapal pukat cincin teri, Rincian rata-rata pungutan lelang pukat cincin teri di PPP Larangan dapat dilihat pada Tabel 7.

Berdasarkan data pada Tabel 7, terlihat bahwa pada kapal berukuran 5 GT, 10 GT dan 15 GT memiliki beban pungutan lelang yang tidak linier, disebabkan kapal 10 GT menghasilkan nilai peneriman paling besar diantara ketiganya, semakin besar nilai penerimaan maka semakin besar pula beban pungutan lelangnya.

Menurut (Isep 2002) yang diacu dalam (Alan et al. 2015), sistem bagi hasil mempengaruhi besarnya pembagian pendapatan yang diterima oleh nelayan buruh dan nelayan pemilik, jenis alat tangkap yang digunakan dalam operasi penangkapan dan jumlah nelayan yang terlibat dalam usaha penangkapan, dimana sistem bagi hasil yang berlaku sudah melembaga dalam kehidupan masyarakat. Besaran upah bagi hasil dijelaskan dalam Tabel 8. 
Tabel 6 Rata-rata biaya operasional nelayan pukat cincin teri di PPP Larangan tahun 2020

\begin{tabular}{|c|c|c|c|c|c|c|c|c|c|c|}
\hline \multirow[b]{2}{*}{$\begin{array}{l}\mathrm{N} \\
\mathrm{o}\end{array}$} & \multirow[b]{2}{*}{$\begin{array}{c}\text { Pengelu } \\
\text { aran }\end{array}$} & \multicolumn{3}{|c|}{ Pukat Cincin Teri 5 GT } & \multicolumn{3}{|c|}{ Pukat Cincin Teri 10 GT } & \multicolumn{3}{|c|}{ Pukat Cincin Teri 15 GT } \\
\hline & & $\begin{array}{l}\text { Biaya/tr } \\
\text { ip (Rp) }\end{array}$ & $\begin{array}{l}\text { Ban } \\
\text { yak } \\
\text { trip }\end{array}$ & $\begin{array}{c}\text { Biaya/trip } \\
1 \text { tahun } \\
(\mathrm{Rp})\end{array}$ & $\begin{array}{l}\text { Biaya/tr } \\
\text { ip (Rp) }\end{array}$ & $\begin{array}{l}\text { Ban } \\
\text { yak } \\
\text { trip }\end{array}$ & $\begin{array}{c}\text { Biaya/trip } \\
1 \text { tahun } \\
(\mathrm{Rp})\end{array}$ & $\begin{array}{l}\text { Biaya/tr } \\
\text { ip (Rp) }\end{array}$ & $\begin{array}{l}\text { Ban } \\
\text { yak } \\
\text { trip }\end{array}$ & $\begin{array}{c}\text { Biaya/trip } 1 \\
\text { tahun }(\mathrm{Rp})\end{array}$ \\
\hline 1 & Solar & 150.000 & 115 & 17.250 .000 & 250.000 & 125 & 31.250 .000 & 350.000 & 126 & 44.100 .000 \\
\hline 2 & Beras & 13.500 & 115 & 1.552 .500 & 13.500 & 125 & 1.687 .500 & 13.500 & 126 & 1.701 .000 \\
\hline 3 & $\begin{array}{l}\text { Lauk } \\
\text { pauk }\end{array}$ & 0 & 115 & 0 & 0 & 125 & 0 & 0 & 126 & 0 \\
\hline 4 & $\begin{array}{c}\text { Air } \\
\text { minum }\end{array}$ & 0 & 115 & 0 & 0 & 125 & 0 & 0 & 126 & 0 \\
\hline 5 & Teh & 20.000 & 115 & 2.300 .000 & 20.000 & 125 & 2.500 .000 & 20.000 & 126 & 2.520 .000 \\
\hline 6 & Gula & 3.000 & 115 & 345.000 & 3.000 & 125 & 375.000 & 3.000 & 126 & 378.000 \\
\hline 7 & Rokok & 16.500 & 115 & 1.897 .500 & 16.500 & 125 & 2.062 .500 & 16.500 & 126 & 2.079 .000 \\
\hline 8 & Es balok & 10.000 & 115 & 1.150 .000 & 10.000 & 125 & 1.250 .000 & 10.000 & 126 & 1.260 .000 \\
\hline & umlah & 213.000 & & 24.495 .000 & 313.000 & & 39.125 .000 & 413.000 & & 52.038 .000 \\
\hline
\end{tabular}

Tabel 7 Rata-rata pungutan lelang pukat cincin teri di PPP Larangan tahun 2020

\begin{tabular}{lrrr}
\hline & \multicolumn{3}{c}{ Jenis Kapal } \\
\cline { 2 - 4 } & \multicolumn{1}{c}{ 5 GT } & \multicolumn{1}{c}{$10 \mathrm{GT}$} & \multicolumn{1}{c}{ GT } \\
\hline Penerimaan (Rp) & 299.370 .899 & 458.452 .264 & 198.007 \\
Pungutan Lelang (Rp) & 14.968 .545 & 22.922 .613 & 18.559 .900 \\
\hline
\end{tabular}

Tabel 8 Bagi hasil

\begin{tabular}{lrrrr}
\hline \multirow{2}{*}{ No } & \multirow{2}{*}{ Jenis } & \multicolumn{3}{c}{ Jumlah $(\mathrm{Rp})$} \\
\cline { 3 - 5 } & \multicolumn{1}{c}{$5 \mathrm{GT}$} & \multicolumn{1}{c}{$10 \mathrm{GT}$} & \multicolumn{1}{c}{$15 \mathrm{GT}$} \\
\hline 1. & Penerimaan hasil penjualan ikan & 299.370 .899 & 458.452 .264 & 371.198 .007 \\
2. & Biaya operasional & 24.495 .000 & 39.125 .000 & 52.038 .000 \\
3. & Pungutan lelang & 14.968 .545 & 22.922 .613 & 18.559 .900 \\
\hline & Sisa & 259.907 .354 & 396.404 .651 & 300.600 .107 \\
\hline & Nelayan pemilik & 129.953 .677 & 198.202 .325 & 150.300 .053 \\
\hline & Nelayan buruh & 129.953 .677 & 198.202 .325 & 150.300 .053 \\
\hline
\end{tabular}

Secara otomatis Tabel 8 menunjukan nilai bagi hasil pada kapal 10 GT menjadi lebih besar dari ketiganya. Dengan demikian, rincian total biaya variabel yang dikeluarkan nelayan pukat cincin teri di PPP Larangan terlihat pada Tabel 9.

Tabel 9 Biaya variabel usaha perikanan tangkap pukat cincin teri di PPP Larangan tahun 2020

\begin{tabular}{ccrrr}
\hline \multirow{2}{*}{ No } & \multirow{2}{*}{ Jenis Biaya Variabel } & \multicolumn{3}{c}{ BiayaVariabel (Rp) } \\
\cline { 3 - 5 } & & \multicolumn{1}{c}{5 GT } & \multicolumn{1}{c}{$10 \mathrm{GT}$} & \multicolumn{1}{c}{ GT } \\
\hline 1 & Biaya operasional & 24.495 .000 & 39.125 .000 & 52.038 .000 \\
2 & Pungutan lelang & 14.968 .545 & 22.922 .613 & 18.559 .900 \\
3 & Upah bagi hasil & 129.953 .677 & 198.202 .325 & 150.300 .053 \\
\hline \multicolumn{2}{c}{ Jumlah } & 169.417 .222 & 260.249 .938 & 220.897 .953 \\
\hline
\end{tabular}

Tabel 10.

Dari perhitungan di atas, diperoleh biaya total yang rinciannya adalah sebagai berikut pada 
Tabel 10 Rata-rata biaya total nelayan pukat cincin teri di PPP Larangan tahun 2020

\begin{tabular}{llccr}
\hline \multirow{2}{*}{ No } & \multirow{2}{*}{ Jenis Biaya } & \multicolumn{3}{c}{ Jumlah Biaya per Tahun (Rp) } \\
\cline { 2 - 5 } & & $5 \mathrm{GT}$ & $10 \mathrm{GT}$ & \multicolumn{1}{c}{$15 \mathrm{GT}$} \\
\hline 1 & Biaya tetap & 47.611 .917 & 65.219 .643 & 77.941 .667 \\
2 & Biaya variable & 169.417 .222 & 260.249 .938 & 220.897 .953 \\
\hline \multicolumn{2}{l}{ Jumlah } & 217.029 .139 & 325.469 .581 & 298.839 .620 \\
\hline
\end{tabular}

Penerimaan

Nilai penerimaan yang diperoleh kapal perikanan pukat cincin teri dalam melakukan operasi penangkapan ikan selama satu tahun terlihat pada Tabel 11.

Tabel 11 Rata-rata Penerimaan selama tahun 2020 (dalam rupiah)

\begin{tabular}{|c|c|c|c|c|}
\hline & \multicolumn{3}{|c|}{ Jenis Penerimaan } & \multirow[b]{2}{*}{ Jumlah (Rp) } \\
\hline & $\begin{array}{l}\text { Penerimaan per } \\
\text { trip di musim } \\
\text { puncak }\end{array}$ & $\begin{array}{l}\text { Penerimaan per } \\
\text { trip di musim } \\
\text { biasa }\end{array}$ & $\begin{array}{l}\text { Penerimaan per } \\
\text { trip di musim } \\
\text { paceklik }\end{array}$ & \\
\hline \multicolumn{5}{|c|}{ Kapal Ukuran 5 GT } \\
\hline Min & 93.375 .222 & 156.662 .752 & 44.200 .473 & 294.849 .706 \\
\hline Max & 95.106 .412 & 163.160 .044 & 47.924 .186 & 302.227 .425 \\
\hline Average & 94.313 .621 & 159.286.331 & 45.770 .947 & 299.370 .899 \\
\hline \multicolumn{5}{|c|}{ Kapal Ukuran 10 GT } \\
\hline Min & 154.816 .005 & 226.655 .095 & 65.205 .353 & 453.223 .667 \\
\hline Max & 159.766 .972 & 252.864 .511 & 73.629 .886 & 477.828 .884 \\
\hline Average & 157.174.442 & 233.660.237 & 67.617 .584 & 458.452 .264 \\
\hline \multicolumn{5}{|c|}{ Kapal Ukuran 15 GT } \\
\hline Min & 136.641 .042 & 177.303 .046 & 42.978 .147 & 357.474 .459 \\
\hline Max & 137.193.266 & 183.551 .687 & 64.728 .825 & 384.921 .554 \\
\hline Average & 136.917.154 & 180.427 .367 & 53.853 .486 & 371.198 .007 \\
\hline
\end{tabular}

Berdasarkan data pada Tabel 11 terlihat bahwa nilai rata-rata penerimaan kapal 10 GT lebih besar dari ketiganya di semua musim.

Pendapatan

Pendapatan yang diperoleh oleh kapal pukat cincin teri selama 1 tahun terlihat pada Tabel 11.

Tabel 12 Rata-rata Pendapatan selama tahun 2020

\begin{tabular}{lr}
\hline \multicolumn{2}{l}{ Pendapatan Bersih per Tahun (Rp) } \\
\hline Kapal Ukuran 5 GT & 299.370 .899 \\
\hline Penerimaan & 217.029 .139 \\
Biaya Total & 82.341 .760 \\
Pendapatan Bersih & \\
\hline Kapal Ukuran 10 GT & 458.452 .264 \\
\hline Penerimaan & 325.469 .581 \\
Biaya Total & 132.982 .683 \\
Pendapatan Bersih & \\
\hline Kapal Ukuran 15 GT & 371.198 .007 \\
\hline Penerimaan & 298.839 .620 \\
Biaya Total & 72.358 .387 \\
Pendapatan Bersih
\end{tabular}


Berdasarkan data pada Tabel 12 terlihat bahwa nilai rata-rata pendapatan bersih kapal 10 GT lebih besar dari ketiganya, sedangkan kapal 15 GT paling kecil dari ketiganya.

\section{Analisis Kelayakan Finansial Pukat Cincin Teri}

Tabel 13 Hasil analisis kelayakan usaha penangkapan pukat cincin teri di PPP Larangan

\begin{tabular}{lccc}
\hline \multicolumn{1}{c}{ Analisis Finansial } & Kapal 5 GT & Kapal 10 GT & Kapal 15 GT \\
\hline NPV & Rp290.569.703 & Rp470.448.109 & Rp141.442.890 \\
IRR & $14 \%$ & $15 \%$ & $4 \%$ \\
R/C Ratio & 1,38 & 1,41 & 1,24 \\
BEP & Rp109.682.332 & Rp150.856.418 & Rp192.493.553 \\
PP & 4,42 & 4,04 & 8,93 \\
ROI & $22,68 \%$ & $24,85 \%$ & $11,20 \%$ \\
\hline
\end{tabular}

a. Net Present Value(NPV)

Digunakan untuk menilai manfaat investasi, yaitu mengetahui nilai kini dari manfaat bersih usaha yaitu dengan menggunakan Net Present Value (NPV), dengan cara melihat selisih penerimaan usaha tahun ke-a dengan biaya proyek pada tahun ke-a dengan tingkat suku bunga yang berlaku. Modal usaha penangkapan pukat cincin teri ukuran 5 GT, 10 GT, dan 15 GT di (PPP) Pelabuhan Perikanan Pantai Larangan menggunakan present value 11,25\%. Diperoleh nilai NPV dari kapal pukat cincin teri 5 GT yaitu Rp290.569.703, kapal 10 GT yaitu Rp470.448.109 dan kapal 15 GT yaitu Rp141.442.890. Nilai NPV pada ketiga kapal pukat cincin teri tersebut seluruhnya memiliki nilai NPV > 0, yang berarti ketiga usaha penangkapan pukat cincin teri tersebut layak dijalankan. Jika dibandingkan kapal 10 GT memiliki nilai NPV tertinggi yaitu sebesar Rp470.448.109, yang berarti usaha penangkapannya paling layak untuk dijalankan.

\section{b. Internal Rate of Return (IRR)}

Nilai IRR mempunyai dua kriteria yaitu jika nilai IRR lebih besar dari tingkat suku bunga maka investasi usaha layak untuk dijalankan, sedangkan jika nilai IRR lebih kecil dari tingkat suku bunga maka investasi usaha tidak layak dijalankan (Johannes et al. 2015). Nilai IRR dari kapal 5 GT yaitu 14\%, dan pada kapal 10 GT yaitu 15\%. Keduanya dikatakan layak karena usaha penangkapan pukat cincin teri tersebut lebih besar dari suku bunga bank Mandiri yaitu 11,25\%, sedangkan nilai IRR dari kapal pukat cincin teri ukuran 15 GT yaitu 4\%, lebih kecil dari suku bunga bank Mandiri yaitu $11,25 \%$, sehingga kelayakan usahanya dinyatakan tidak layak dijalankan. Nilai IRR dari usaha penangkapan pukat cincin teri 10 GT lebih besar 1\% dari nilai IRR usaha penangkapan pukat cincin teri $5 \mathrm{GT}$, berarti usaha penangkapan pukat cincin teri $10 \mathrm{GT}$ paling layak dijalankan.

\section{c. Revenue-Cost Ratio ( $R / C$ Ratio)}

Hasil dari analisis R/C ratio, diperoleh hasil bahwa nilai R/C ratio pada kapal 5 GT 1,38. Artinya setiap pengoperasian penangkapan yang dilakukan akan memperoleh nilai penerimaan sebesar 1,38 kali lipat dari biaya yang dikeluarkan. Pada kapal $10 \mathrm{GT}$ nilai $R / C$ ratio 1,41 . Artinya setiap pengoperasian penangkapan yang dilakukan akan memperoleh nilai penerimaan 1,41 kali lipat dari biaya yang dikeluarkan. Sedangkan pada kapal 15 GT nilai $R / C$ ratio 1,24 . Artinya setiap pengoperasian penangkapan yang dilakukan akan memperoleh nilai penerimaan 1,24 kali lipat dari biaya yang dikeluarkan. Berdasarkan nilai-nilai tersebut, dapat dikatakan bahwa usaha penangkapan dengan kapal pukat cincin teri berukuran $10 \mathrm{GT}$ paling menguntungkan dari ketiganya.

\section{d. BEP (Break Event Point)}

Berdasarkan hasil analisis menunjukkan bahwa BEP produksi (harga) kapal 5 GT mencapai Rp109.682.332; yang berarti nelayan tidak memperoleh keuntungan dan tidak mengalami kerugian 
apabila mendapatkan penghasilan sebesar Rp109.682.332 tiap tahunnya. Kapal 5 GT dinyatakan untung dengan penghasilan sebesar Rp299.370.899.

BEP produksi (harga) pada kapal 10 GT mencapai Rp150.856.418 yang berarti nelayan tidak memperoleh keuntungan dan tidak mengalami kerugian apabila mendapatkan penghasilan sebesar Rp150.856.418 tiap tahunnya. Kapal 10 GT dinyatakan untung dengan penghasilan sebesar Rp458.452.264.

BEP produksi (harga) pada kapal 15 GT mencapai Rp192.493.553 yang berarti nelayan tidak memperoleh keuntungan dan tidak mengalami kerugian apabila mendapatkan penghasilan sebesar Rp192.493.553 tiap tahunnya. Kapal 15 GT dinyatakan untung dengan penghasilan sebesar Rp371.198.007.

e. PP (Payback Period)

Digunakan untuk mengetahui periode pengembalian nilai investasi penangkapan ikan sehingga dapat diketahui lamanya waktu yang diperlukan agar modal yang ditanamkan pada usaha investasi tersebut dapat kembali seluruhnya, diperlukan perhitungan payback period (Setyawan et al. 2013). Jika waktu pengembalian modal usaha kurang dari 3 tahun, maka tingkat pengembalian modal usaha dikategorikan cepat. Jika nilai PP lebih dari 3 tahun dan kurang dari 5 tahun maka dikategorikan dengan tingkat pengembalian sedang dan apabila nilai PP lebih dari 5 tahun maka tingkat pengembalian dikategorikan lambat. Hasil perhitungan pada kapal 5 GT didapatkan PP sebesar 4,42. Artinya bahwa pada kapal 5 GT akan kembali modal pada 4 tahun 5 bulan. Pada kapal 10 GT didapatkan PP sebesar 4,04. Artinya bahwa pada kapal 10 GT akan kembali modal pada 4 tahun 30 hari. Sedangkan pada kapal 15 GT didapatkan PP sebesar 8,93. Artinya bahwa pada kapal 15 GT akan kembali modal pada 8 tahun 11 bulan. Kapal pukat cincin teri 10 GT dinyatakan paling cepat pengembalian modalnya. PP dari kapal pukat cincin teri ukuran 5 GT dan 10 GT tergolong dalam tingkat pengembalian sedang dan kapal 15 GT tergolong dalam tingkat pengembalian lambat.

\section{f. Return of Investment (ROI)}

Nilai ROI untuk kapal 5 GT sebesar 22,68\%, yang berarti perbandingan besarnya keuntungan yang diperoleh dengan investasi yang ditanamkan adalah baik artinya setiap modal sebesar Rp100, diperoleh keuntungan Rp22,68. Sama halnya dengan nilai ROI untuk kapal 10 GT sebesar 24,85\%, atinya setiap modal sebesar Rp100, diperoleh keuntungan Rp24,85. Sedangkan nilai ROI untuk kapal 15 GT adalah sebesar $11,20 \%$, yang berarti setiap modal sebesar Rp.100, diperoleh keuntungan Rp11,20. Dilihat dari nilai ROI-nya maka pengoperasian kapal $10 \mathrm{GT}$ yang paling menguntungkan dari ketiganya.

\section{KESIMPULAN DAN SARAN}

1. Pengoperasian kapal pukat cincin teri ukuran 5 GT, 10 GT dan 15 GT di PPP. Larangan, Kabupaten Tegal diperoleh hasil perhitungan:

a. Secara ekonomi, investasi usaha pengoperasian kapal 5 GT Rp363.134.000, biaya total Rp217.029.139/tahun, pendapatan Rp299.370.899 dan keuntungan Rp82.341.760/tahun.

b. Investasi usaha pengoperasian kapal 10 GT Rp535.200.000, biaya total Rp325.469.581/tahun, pendapatan Rp458.452.264 dan keuntungan Rp132.982.682/tahun.

c. Investasi usaha pengoperasian kapal 15 GT Rp646.220.000, biaya total Rp298.839.620/tahun, pendapatan Rp371.198.007 dan keuntungan Rp72.358.386/tahun.

d. Pengoperasian kapal pukat cincin teri 10 GT dinyatakan mampu menghasilkan keuntungan terbesar dari ketiganya. 
2. Analisa kelayakan usaha pengoperasian kapal 5 GT dan 10 GT dinyatakan layak dan menguntungkan. Dimana nilai NPV, IRR, R/C Ratio, BEP, PP, ROI memenuhi syarat untuk dapat dikategorikan usaha penangkapan ikan yang layak, yaitu:

a. $\mathrm{NPV}=\mathrm{Rp} 290.569 .703, \mathrm{IRR}=14 \%, R /$ C ratio $=1,38, \mathrm{BEP}=\mathrm{Rp} 109.682 .332, \mathrm{PP}=4,42$, dan $\mathrm{ROI}=$ $22,68 \%$ untuk kapal 5 GT,

b. Kapal 10 GT NPV= Rp470.448.109, IRR=15\%, $R / C$ ratio= $1,41, \mathrm{BEP}=\mathrm{Rp} 150.856 .418, \mathrm{PP}=$ 4,04 , dan $\mathrm{ROI}=24,85 \%$.

c. Jika dibandingkan secara kelayakan usaha, kapal 10 GT lebih menguntungkan dan lebih layak dijalankan.

d. Kapal 15 GT dinyatakan kurang menguntungkan dan kurang layak dijalankan dengan perolehan nilai $\mathrm{NPV}=\mathrm{Rp} 141.442 .890, \mathrm{IRR}=4 \%, R / C$ ratio $=1,24, \mathrm{BEP}=\mathrm{Rp} 192.493 .553, \mathrm{PP}=$ 8,93, dan $\mathrm{ROI}=11,20 \%$.

\section{UCAPAN TERIMA KASIH}

Tulisan ini merupakan bagian dari hasil penelitian Tesis dengan judul Pengembangan Usaha Perikanan Pukat Cincin Teri di Perairan Laut Kabupaten Tegal-Jawa Tengah atas bantuan dana Penelitian dari Program Beasiswa Pusat Pendidikan Kementerian Kelautan dan Perikanan Tahun 2020.

\section{DAFTAR PUSTAKA}

Alan, W., Hendrik, H., \& Nugroho, F. 2015. Sistem Bagi Hasil USAha Purse Seine di Pelabuhan Perikanan Samudera (Pps) Bungus Kota Padang Provinsi Sumatera Barat. Riau University,

Fachrussyah, Z. C., \& Yantu, I. 2018. Kajian Usaha Perikanan Purse Seine (Studi Kasus pada Kelompok KM. Mentari 8888 Milik PT. Mentari Samudera Raya, Bitung-Sulawesi Utara). JAMBURA: Jurnal Ilmiah Manajemen dan Bisnis, 1(3), 299-308.

Husein, U. 2015. Studi Kelayakan Bisnis, p. Edisi Ketiga. Jakarta.

Jakfar, K. D. 2009. Studi Kelayakan Bisnis (Edisi Kedua ed.). Jakarta: Prenada Media Group.

Johannes, S., Wisudo, S. H., \& Nurani, T. W. 2015. Analisis Faktor Produksi dan Kelayakan Usaha Perikanan Purse Seine di Kecamatan Salahutu Kabupaten Maluku Tengah. Jurnal Aplikasi Manajemen, 13(2), 335-343.

Kusuma, P. T. W. W., \& Mayasti, N. K. I. 2014. Analisa kelayakan finansial pengembangan usaha produksi komoditas lokal: mie berbasis jagung. Agritech, 34(2), 194-202.

Peraturan Menteri Kelautan dan Perikanan nomor 58/PERMEN-KP/2020 tentang perikanan tangkap. Berita Negara Republik Indonesia Tahun 2020 Nomor 1397.

Pujianto, H. B., \& Wijayanto, D. 2013. Feasibility Study Analysis Financial Aspect to Marine Fisheries Business of Mini Purse Seine With Net Different Size in PPI Ujungbatu Jepara Regency. Journal of Fisheries Resources Utilization Management and Technology, 2(2), 125-126.

Putri, D. A., \& Dewi, S. 2019. Analisa Usaha Perikanan Tangkap Bolga (Mini Purse Seine) Dengan Hasil Tangkapan Teri (Engraulidae) Di Desa Gebang Mekar, Kabupaten Cirebon Jawa Barat. Barakuda 45: Jurnal Ilmu Perikanan dan Kelautan, 1(2), 88-103.

Sayuti, M. 2008. Analisis Kelayakan Pabrik. Yogyakarta: Graha Ilmu. 
Setyawan, R., Wibowo, B. A., \& Pramonowibowo, P. 2013. Analisis Usaha Perikanan Pada Alat Tangkap Bubu Di Perairan Rawapening Desa Lopait Kecamatan Tuntang Kabupaten Semarang. Journal of Fisheries Resources Utilization Management and Technology, 2(3), 131-141.

Sobari, M. P., \& Isnaini, I. 2009. Analisis Teknik Dan Finansial Unit Penangkapan Muroami Di Perairan Kepulauan Seribu. Buletin PSP, 18(2).

Sofyani, T. 2012. Pengorganisasian Dan Analisis Usaha Perikanan Keramba Di Waduk Plta Koto Panjang Kabupaten Kampar. Berkala Perikanan Terubuk, 38(1).

Suharyanto, S., Saputra, R. S. H., Mufid, M. A., \& Sutono, D. 2020. Analisis Usaha Perikanan Purse Seine di Perairan Kendari, Provinsi Sulawesi Tenggara. PELAGICUS, 1(1), 21-29.

Undang-undang Republik Indonesia Nomor 7 Tahun 2016 tentang Perlindungan dan Pemberdayaan Nelayan, Pembudi Daya Ikan, dan Petambak Garam. Lembaran Negara Republik Indonesia Tahun 2016 Nomor 68.

Undang-undang Republik Indonesia Nomor 45 Tahun 2009 tentang Perubahan Atas Undang-undang Nomor 31 Tahun 2004 tentang Perikanan. Lembaran Negara Republik Indonesia Tahun 2009 Nomor 154. 